advocated has been successfully tried in a small town with its own maternity unit in Northamptonshire and is now being introduced in the Barratt Maternity Home itself.

Finally, it should be pointed out that in the area covered by the study a large proportion of antenatal care is provided by family doctors, and all those on the obstetric list have access to the various general-practitioner maternity units. Since acceptance on the obstetric list for new applicants is now almost entirely confined to those with postgraduate obstetric experience, it is clear that the future general-practitioner maternity service will show an increasing proportion of general-practitioner obstetricians with special interest and skill. Just as midwives should have access, so such general-practitioner obstetricians should be provided with every facility to follow the care of their patients in specialist obstetric units.

\section{Summary}

A survey of 503 (233 domiciliary and 270 hospital) normal confinements has been analysed with regard to three aspects of obstetric care.

Almost a quarter of the women delayed seeking antenatal care until the 20th week of pregnancy or later, and this state of affairs was particularly marked among those of high parity who were subsequently confined in hospital.

Perineal repair was more commonly necessary in hospital patients, and the need for it diminished with descending social class and increasing parity. Only about half of the mothers were found to be taking iron regularly 28 days after confinement.

By 28 days the proportion of mothers in each social class who were breast-feeding their babies was higher in those who had been confined at home than in those delivered in hospital, though such feeding diminished with descending social class and with increasing parity. With the exception of first babies, there was a social-class gradient for each parity, both at 10 and 28 days after delivery.

Among mothers there appeared to be little to choose between hospital and home delivery so far as illness in the first 28 days after confinement was concerned, whereas in the case of infants the advantage appeared to lie on the side of home confinement.

On the question of early discharge from hospital, a follow-up of mothers and babies discharged within four days of delivery showed that they had slightly more minor illness compared with those discharged later, but the difference could easily be attributable to chance.

In view of the increasing trend towards shorter hospital stay, it is suggested that a combined hospital-domiciliary midwifery service is required, in which midwives would have continuous supervision of mothers both at home and in hospital.

An investigation into choice of place of confinement showed that $63 \%$ of all mothers would prefer to have their next confinement at home, the percentages for those delivered at home or in hospital being $94 \%$ and $37 \%$ respectively. Bearing in mind that $75 \%$ of the mothers in the area have hospital confinements, preference for a home or hospital confinement is equally divided. This again points to the conclusion that a combined hospital and domiciliary midwifery service would offer benefits from all points of view.

Thanks are due to the staff of the Barratt Maternity Home and to the midwives and health visitors of Northamptonshire County Council for undertaking the field work of this study, and to the staff of the Statistical Unit of the Oxford Regional Hospital Board for the analysis.

\section{REFERENCES}

Butler, N. R., and Bonham, D. G. (1963). Perinatal Mortality. London. Douglas, J., Edgar, W., and Horne, K. (1961). Med. Offr, 106, 333. Feldstein, M. S. (1965). Opl Res. Q., 16, 65 . FitzGerald, T. B. (1959). Lancet, 1, 403.

Foster, D. S. (1957). Brit. med. \%., 1, 1120.

Institute of Municipal Treasurers and Accountants (1965). Local Health Services Statistics 1963-1964. London.
S

McEwan, E. D. (1964). Lancet, 2 , 744.

Ministry of Health (1959). Report of the Maternity Services Committee (Cranbrook Committee). H.M.S.O., London.
(1965). Hort

(1965). Hospital Costing Returns. Pt. 1, 1964-1965. H.M.S.O., London.

Pinker, G. D., and Fraser, A. C. (1964). Brit. med. 7., 2, 99.

Reid, J. J. A. (1965). The Health of Northamptonshire in 1964.

Rhodes, P. (1964). Lancet, 2, 746.

Theobald, G. W. (1959). Brit. med. 7., 2, 1364.

- (1962). Lancet, 1, 735 .

\title{
Dosage of Gentamicin for Pseudomonas Infections
}

\author{
J. H. DARRELL,* M.B., D.C.H., M.C.PATH. ; PAMELA M. WATERWORTH,† F.I.M.L.T.
}

Brit. med. F., 1967, 2, 535-537

Gentamicin is a recently described addition to the aminoglycoside group of antibiotics, which includes streptomycin, neomycin, and kanamycin (Weinstein et al., 1963). It is active in vitro against a wide range of Gram-negative and Grampositive bacteria, including Pseudomonas aeruginosa and neomycin-resistant staphylococci (Barber and Waterworth, 1966), streptococci being the only common pathogens showing uniform moderate-to-high resistance. Like other members of the group it is ototoxic, and vestibular damage has been reported in patients with impaired renal function (Bulger et al., 1963 ; Sweedler et al., 1963 ; Jao and Jackson, 1964).

The recommended dose is only $40 \mathrm{mg}$. twice daily. The observations recorded here were routine clinical investigations,

\footnotetext{
- Lecturer, Department of Bacteriology, Royal Postgraduate Medical School, London W.12; Honorary Consultant Bacteriologist,

t Research Assistant, Department of Bacteriology, Royal Postgraduate

and the purpose of this preliminary report is to suggest that this dosage is inadequate for the treatment of pseudomonas infections and is encouraging the development of resistance.

\section{Materials and Methods}

All patients were receiving gentamicin for infections due to Ps. aeruginosa known to be at least moderately sensitive to a $10-\mu \mathrm{g}$. disc.

Minimum inhibitory concentrations were done by the plate dilution technique with Oxoid blood agar base No. 2 and a light inoculum (a 1 in 500 dilution of an overnight broth culture).

Gentamicin assays were done by the vertical diffusion technique of Mitchison and Spicer (1949), the Oxford staphylococcus being used. Penicillin when present was inactivated by penicillinase, and when erythromycin or methicillin was present 
Escherichia coli (N.C.I.B. 8879) was used as the assay organism.

\section{Results}

The blood levels attained in three normal subjects after the intramuscular injection of $40 \mathrm{mg}$. of gentamicin are shown in the Chart. Only in subject A was a peak level of $4 \mu \mathrm{g} . / \mathrm{ml}$. reached; in subject $C$ it did not exceed $2 \mu \mathrm{g} . / \mathrm{ml}$. These

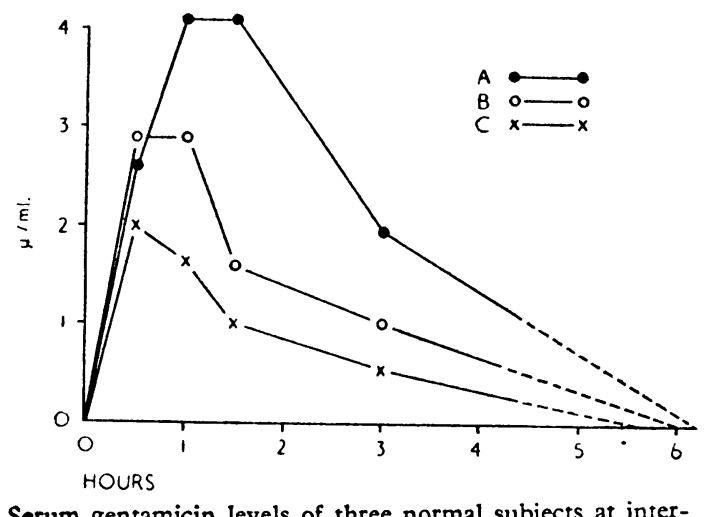

Serum gentamicin levels of three normal subjects at intervals after a single 40 -mg. dose.

differences cannot be explained by weight. $A$ and $C$ were males weighing 168 and $151 \mathrm{lb}$. (76.2 and $68.5 \mathrm{~kg}$.) respectively, B was a female weighing $125 \mathrm{lb}$. (56.7 kg.).

The results of assays in patients, many with some degree of renal impairment, are given in Table $\mathrm{I}$.

Table I.-Serum Gentamicin Levels in Patients Under Treatment

\begin{tabular}{|c|c|c|c|c|}
\hline Case No. & $\begin{array}{l}\text { Dose } \\
\text { (mg.) }\end{array}$ & $\begin{array}{l}\text { Blood Urea } \\
\text { (mg./100 ml.) }\end{array}$ & $\begin{array}{l}\text { Interval After } \\
\text { Last Dose } \\
\text { (hours) }\end{array}$ & $\begin{array}{l}\text { Blood Level } \\
(\mu \mathrm{g} . / \mathrm{ml} .)\end{array}$ \\
\hline 1 & 40 & $56-170$ & $\begin{array}{l}3 \\
41\end{array}$ & $\begin{array}{l}2.0 \\
1.3\end{array}$ \\
\hline 2 & 40 & $\begin{array}{l}70-48 \\
150\end{array}$ & $\begin{array}{l}3 \\
3 \text { days } \\
9 \text { ”" }\end{array}$ & $\begin{array}{l}2 \cdot 0 \\
2 \cdot 8 \\
1.0\end{array}$ \\
\hline 3 & 40 & $52-74$ & $\begin{array}{l}2 \\
6\end{array}$ & $\begin{array}{l}3 \cdot 1 \\
1 \cdot 4\end{array}$ \\
\hline 4 & 40 & 26 & $\begin{array}{l}1 \\
5 \frac{1}{2}\end{array}$ & $\begin{array}{l}3.9 \\
1.3\end{array}$ \\
\hline 5 & 40 & 30 & $\begin{array}{l}1 \\
8\end{array}$ & $\begin{array}{r}2 \cdot 8 \\
\text { Nil }\end{array}$ \\
\hline & 40 & $122-242^{*}$ & $\frac{1 \frac{1}{2}}{6}$ & $\begin{array}{l}3 \cdot 2 \\
2 \cdot 8\end{array}$ \\
\hline 6 & $\begin{array}{c}\text { Increased to } \\
80\end{array}$ & & $6^{1 \frac{1}{2}}$ & $\begin{array}{r}10 \cdot 1 \\
3 \cdot 4\end{array}$ \\
\hline 7 & 80 & - & $\begin{array}{l}1 \\
8\end{array}$ & $\begin{array}{l}5 \cdot 4 \\
3 \cdot 6\end{array}$ \\
\hline
\end{tabular}

- Patient on continuous peritoneal dialysis (dialysis fluid contained 2-6 $\mu \mathrm{g}$. of gentamicin per ml.).

Table II shows the minimum inhibitory concentrations of 45 strains of Ps. aeruginosa isolated in the clinical laboratory during the last two months. These minimum inhibitory concentrations are rather higher than those reported in a previous publication from this department (Barber and Waterworth, 1966) but agree well with those found by some other authors (Jao and Jackson, 1964 ; Klein et al., 1964). The differences between the two series from Hammersmith Hospital have been shown to be due to the use of different media in the tests.

Three of the four strains inhibited only by 16 and $32 \mu \mathrm{g} . / \mathrm{ml}$. were isolated after unsuccessful treatment with gentamicin. Another strain from an unsuccessfully treated case showed a TABLE II.-Activity of $\begin{gathered}\text { Gentamicin Against Clinical Isolates of Ps. } \\ \text { aeruginosa }(45 \text { Strains })\end{gathered}$

No. of Strains with Minimum Inhibitory Concentration ( $\mu \mathrm{g} . / \mathrm{ml}$.) of:

\begin{tabular}{r|r|r|r|r|r|r|r|r}
\hline 64 & 32 & 16 & 8 & 4 & 2 & 1 & 0.5 & 0.25 \\
\hline- & 2 & 2 & 5 & 20 & 12 & - & - & 4
\end{tabular}

16-fold increase in minimum inhibitory concentration as compared with the original isolate $(0.25-4 \mu \mathrm{g} . / \mathrm{ml}$.). The sensitivity of paired strains from three of these cases to the other aminoglycosides is given in Table III, and shows a similar relative increase in resistance to all. Brief clinical reports of these unsuccessful cases are given below. In four urinary tract infections, sterilized during treatment but relapsing later, the minimum inhibitory concentration of the organism remained unchanged. TABLE III.-Minimum Inhibitory Concentrations ("g./ml.) of Different
Aminoglycosides for Strains of Ps. aeruginosa Isolated Before and After Treatment with Gentamicin

\begin{tabular}{|c|c|c|c|c|c|c|c|}
\hline \multicolumn{2}{|c|}{ Case No. } & $\begin{array}{l}\text { Genta- } \\
\text { micin }\end{array}$ & $\begin{array}{l}\text { Kana- } \\
\text { mycin }\end{array}$ & $\begin{array}{l}\text { Neo- } \\
\text { mycin }\end{array}$ & $\begin{array}{c}\text { Fra- } \\
\text { mycetin }\end{array}$ & $\begin{array}{c}\text { Paromo- } \\
\text { mycin }\end{array}$ & $\begin{array}{c}\text { Strepto- } \\
\text { mycin }\end{array}$ \\
\hline 8 & $\left\{\begin{array}{l}1 \\
2\end{array}\right.$ & $\begin{array}{r}4 \\
32\end{array}$ & $\begin{array}{l}125 \\
512\end{array}$ & $\begin{array}{r}32 \\
256\end{array}$ & $\begin{array}{r}32 \\
256\end{array}$ & $\begin{array}{r}512 \\
>512\end{array}$ & $\begin{array}{r}64 \\
256\end{array}$ \\
\hline 2 & $\left\{\begin{array}{l}1 \\
2\end{array}\right.$ & $\begin{array}{r}4 \\
32\end{array}$ & $\begin{array}{l}125 \\
512\end{array}$ & $\begin{array}{r}32 \\
128\end{array}$ & $\begin{array}{r}32 \\
256\end{array}$ & $\begin{array}{r}512 \\
>512\end{array}$ & $\begin{array}{r}64 \\
256\end{array}$ \\
\hline 10 & $\left\{\begin{array}{l}1 \\
2\end{array}\right.$ & $\begin{array}{l}0 \cdot 25 \\
4\end{array}$ & $\begin{array}{r}32 \\
128\end{array}$ & $\begin{array}{r}8 \\
32\end{array}$ & $\begin{array}{r}8 \\
32\end{array}$ & $\begin{array}{r}32 \\
512\end{array}$ & $\begin{array}{r}4 \\
32\end{array}$ \\
\hline
\end{tabular}

\section{Case Reports}

Case 8.-This patient, a man aged 60 with mesenteric artery thrombosis, after resection of several feet of small intestine developed renal failure which required urethral catheterization and intermittent dialysis. Gastrointestinal bleeding from a duodenal ulcer occurred during his oliguric phase and subsequently required vagotomy and pyloroplasty. Urine became infected with Ps. aeruginosa, which was also isolated from the abdominal wounds. Treatment with gentamicin $40 \mathrm{mg}$. eight-hourly failed to improve his condition and strains of Pseudomonas isolated after treatment showed an eightfold increase in resistance.

Case 2.-This patient was a man aged 65 with diabetic gangrene and mild renal impairment (blood urea $70 \mathrm{mg} . / 100 \mathrm{ml}$. falling to $40 \mathrm{mg} . / 100 \mathrm{ml}$. before treatment). The amputation site (middle toe) was infected with Ps. aeruginosa, Proteus mirabilis, and faecal streptococci. Before surgical debridement treatment with local gentamicin $(0.1 \%)$ and systemic gentamicin sulphate $40 \mathrm{mg}$. sixhourly produced a three-hour blood level of $2 \mu \mathrm{g} . / \mathrm{ml}$. After initial clinical and bacteriological improvement Ps. aeruginosa was again isolated and showed an eightfold increase in resistance. Treatment was continued for four weeks, and two days after it was stopped the patient developed severe vertigo. His blood urea had risen from 40 to $150 \mathrm{mg} . / 100 \mathrm{ml}$., and three days after his last dose of gentamicin a serum level of $2.8 \mu \mathrm{g} . / \mathrm{ml}$. was found, with $1 \mu \mathrm{g} . / \mathrm{ml}$. after nine days.

Case 9.-This man, aged 45, had chronic renal failure. While having peritoneal dialysis he developed peritonitis with Ps. aeruginosa, Proteus mirabilis, E. coli, Clostridium welchii, and Candida albicans. Benzylpenicillin with gentamicin $40 \mathrm{mg}$. six-hourly brought temporary improvement, but after treatment a strain of Pseudomonas isolated had a minimum inhibitory concentration of $16 \mu \mathrm{g} . / \mathrm{ml}$.

Case 10.-A man aged 78 with chronic lymphatic leukaemia developed a chest infection with Ps. aeruginosa. Gentamicin by inhalation with a respirator produced no improvement. Systemic gentamicin $40 \mathrm{mg}$. eight-hourly, later increased to six-hourly, was given in two courses of seven days, the second time in combination with other antibiotics. It produced clinical and bacteriological improvement, but immediate relapse occurred when the treatment was stopped. The resistance to gentamicin of strains isolated after treatment had increased 16 -fold $(0.25-4 \mu \mathrm{g} . / \mathrm{ml})$.

\section{Discussion}

The minimum inhibitory concentration of gentamicin for 45 fresh isolates of Ps. aeruginosa was in 29 instances $4 \mu \mathrm{g} . / \mathrm{ml}$. (20 strains) or more. Of three normal subjects given $40 \mathrm{mg}$. of gentamicin intramuscularly only one attained a peak serum level of this order. In each the level had fallen below $2 \mu \mathrm{g} . /$ $\mathrm{ml}$. after three hours-in two of the three to $1 \mu \mathrm{g} . / \mathrm{ml}$. or less. Patients treated with this same dose achieved levels of 2 to $3.9 \mu \mathrm{g} . / \mathrm{ml}$. after two to three hours. These fell to between 1.3 and $2.8 \mu \mathrm{g} . / \mathrm{ml}$. after four and a half to six hours. 
Thus in normal subjects or patients with impaired renal function injection of $40 \mathrm{mg}$. of gentamicin fails in the majority of cases to produce serum levels reaching the minimum inhibitory concentration of clinical isolates of Ps. aeruginosa. With this dose the serum level will rarely exceed the minimum inhibitory concentration by a factor of two, nor will it be maintained for half the interval between doses, though both circumstances are desirable when treating pseudomonas infections.

Serum levels in patients with impaired renal function may gradually build up even on small doses, but this is an inefficient method of treatment calculated to encourage the development of resistance in a bacterial population. In three patients treated unsuccessfully the minimum inhibitory concentration of strains isolated after treatment had increased eightfold. This is the first report of resistance acquired in vivo, and it is interesting that there is a similar increase in the minimum inhibitory concentration of kanamycin, though naturally occurring resistance to kanamycin does not involve gentamicin.

Doses of $80 \mathrm{mg}$. produce more realistic peak levels $-5.4 \mu \mathrm{g} . /$ $\mathrm{ml}$. in one patient, and $10.15 \mu \mathrm{g} . / \mathrm{ml}$. in another in whom the dose was increased during treatment. If treatment with gentamicin is contemplated initial dosage of this order, or possibly even higher, seems necessary. To avoid toxic levels, estimation of serum concentrations is necessary in patients with impaired renal function and probably in the elderly (compare streptomycin). Prolonged courses of treatment are to be avoided. If given in adequate dosage initially treatment is likely to be effective, if it is to succeed at all, in 7 to 10 days.

It is assumed in this discussion that adequate tissue levels are necessary for effective treatment, as they clearly must be for any lesion outside the urinary tract. The concentrations attained in the urine are much higher, and may suffice to overcome a urinary tract infection not involving the renal parenchyma.

The work reported is being continued as a study of the relation of serum levels to results of treatment in urinary infections, complicated and uncomplicated.

\section{Summary}

Blood concentrations were assayed in normal subjects and in patients receiving the recommended dose of gentamicin. These were often found to be lower than the usual minimum inhibitory concentration of this antibiotic for Pseudomonas aeruginosa. The resistance of the infecting strain in three patients given this dose increased during treatment. It is suggested that larger doses, controlled by blood assay, are required for satisfactory therapeutic effects.

We would like to thank Professor L. P. Garrod for his encouragement in preparing this report and our clinical colleagues for allowing us to include reports of cases under their care.

The gentamicin sulphate used was supplied as Genticin by British Schering Limited.

\section{REFERENCES}

Barber, M., and Waterworth, P. M. (1966). Brit. med. F., 1, 203.

Bulger, R.' J., Sidell, S., and Kirby, W. M. M. (1963). Ann. intern. Med., 59, 593 .

Jao, R. L., and Jackson, G. G. (1964). F. Amer. med. Ass., 189, 817

Klein, J. O., Eickhoff, T. C., and Finland, M. (1964). Amer. F. med. Sci., 248, 528.

Mitchison, D. A., and Spicer, C. C. (1949). 7. gen. Microbiol., 3, 184.

Sweedler, D. R., Gravenkemper, C. F., Bulger, R. J., Brodie, J. L., and Kirby, W. M. M. (1963). Antimicrobial Agents and Chemotherapy, p. 157.

Weinstein, M. J., Luedemann, G. M., Oden, E. M., and Wagman, G. H. (1963). Ibid., p. 1

\title{
Parenteral Administration of Gentamicin in Renal Failure: Patients Undergoing Intermittent Haemodialysis
}

\author{
J. R. CURTIS,* M.B., M.R.C.P.; S. J. MCDONALD,* M.B., PH.D.; J. H. WESTON, † L.INST.BIOL.
}

Brit. med. F., 1967, 2, 537-539

Gentamicin is a broad-spectrum antibiotic chemically related to neomycin, kanamycin, and streptomycin (Rosselet et al., 1963 ; Weinstein et al., 1963 ; Barber and Waterworth, 1966). After parenteral administration, elimination is mainly via the kidney in normal subjects, $80-90 \%$ being recoverable in the active form in the urine; a small amount may be found in bile (Black et al., 1963). This study was undertaken to obtain information on blood levels of gentamicin and to assess what dosage revision may be necessary in severe renal failure.

\section{Methods}

Two normal subjects and three patients with terminal renal failure were studied. The patients were maintained on chronic intermittent haemodialysis. Gentamicin was administered therapeutically to two of the patients because of Pseudomonas pyocyanea shunt-site infections and prophylactically to the third. Details of the patients and normal subjects are given

\footnotetext{
- Lecturer in Medicine, Charing Cross Hospital Medical School, Fulham Hospital, London W.6.

+ Microbiologist, Nicholas Research Institute, Slough.
}

in the Table. The patients were dialysed for 14 hours twice weekly by means of a modified two-layer Kiil dialyser with cuprophane membranes (PT 150). Dialysis fluid at $40^{\circ} \mathrm{C}$. was employed in a single pass system (Curtis and de Wardener, 1967). In the Table the plasma creatinine concentration and creatinine clearance and blood urea figures for the three patients are those obtained immediately before beginning intermittent haemodialysis. In each study heparinized plasma samples were obtained before and at varying intervals up to 72 hours after the intravenous administration of $40-80 \mathrm{mg}$. of gentamicin. The

\begin{tabular}{|c|c|c|c|c|c|c|c|}
\hline \multirow[b]{3}{*}{ Subject } & ails of & Three Patients & and & Two $\wedge$ & Normal & cts & ed \\
\hline & \multirow[b]{2}{*}{$\begin{array}{c}\text { Weight } \\
\text { (kg.) }\end{array}$} & \multirow[b]{2}{*}{ Diagnosis } & \multicolumn{2}{|c|}{ Gentamicin } & \multirow{2}{*}{$\begin{array}{c}\text { Plasma } \\
\text { Creatinine } \\
\text { (mg.l } \\
100 \mathrm{ml} .)\end{array}$} & \multirow[b]{2}{*}{$\begin{array}{l}\text { Creatinine } \\
\text { Clearance } \\
\text { (ml./min.) }\end{array}$} & \multirow{2}{*}{$\begin{array}{c}\text { Blood } \\
\text { Urea } \\
\text { (mg./. } \\
100 \mathrm{ml} .)\end{array}$} \\
\hline & & & $\begin{array}{l}\text { Total } \\
\text { Dose } \\
\text { (mg.) }\end{array}$ & $\left|\begin{array}{c}\text { Dura- } \\
\text { tion } \\
\text { (Days) }\end{array}\right|$ & & & \\
\hline Case 1 & 51 & $\begin{array}{c}\text { C.G.N. and } \\
\text { malignant }\end{array}$ & & & & & \\
\hline $\begin{array}{l}\text { A.B. }^{2} \\
\text { C.D. }\end{array}$ & $\begin{array}{l}70 \\
42 \\
80 \\
55\end{array}$ & $\begin{array}{l}\text { hypertension } \\
\text { C.G.N. } \\
\text { Normal } \\
\text { ", }\end{array}$ & $\begin{array}{l}500 \\
170 \\
460 \\
=\end{array}$ & $\begin{array}{l}24 \\
10 \\
26 \\
=\end{array}$ & $\begin{array}{r}20.0 \\
11.9 \\
13.6 \\
0.8 \\
0.9\end{array}$ & $\begin{array}{r}1.0 \\
0.5 \\
0.4 \\
98.0 \\
101.0\end{array}$ & $\begin{array}{r}310 \\
305 \\
250 \\
30 \\
20\end{array}$ \\
\hline
\end{tabular}

